\title{
Происхождение природных газов гигантского Уренгойского месторождения
}

\author{
А.В. Плюснин, О.Е.Кочнева \\ Пермский государственный национальный исследовательский универси- \\ тет, 614600, Пермь, ул. Букирева, 15. E-mail: geolog0112@mail.ru \\ (Статья поступила в редакцию 29 января 2014 г.)
}

\begin{abstract}
Рассмотрены геологическое строение и происхождение мелового (неокомсеноманского) комплекса Уренгойского месторождения Надым-Пурской нефтегазоносной области. Характерной особенностью этой области является развитие мощного неоком-сеноманского комплекса. Данная территория в период от валанжина до сеномана испытывала преимущественно континентальный режим осадконакопления, когда существовали благоприятные условия для захоронения большого количества растительных остатков - исходного материала для массы угольного вещества, содержащегося в породах комплекса. Наличие повышенных концентраций угольного вещества явилось важнейшим генетическим признаком, по которому континентальная толща апт-сеноманского возраста отнесена к типичной угленосной формации. В работе приведена вертикальная и региональная зональность распределения фазового состояния углеводородов, позволяющая прогнозировать фазовое состояние, количественную и качественную характеристики скоплений углеводородов.

Ключевые слова: Западная Сибирь, Надым-Пурская область, Уренгойское месторождение, сеноман, газ, конденсат, катагенез.
\end{abstract}

Уренгойское газоконденсатное месторождение - это крупнейшее месторождение в России. Его общие геологические запасы оцениваются в 16 трлн м ${ }^{3}$ природного газа и 1,2 млрд т газового конденсата. Месторождение находится в северной части Западно - Сибирской низменности. Административно располагается в Пуровском районе Ямало-Ненецкого автономного округа Тюменской области, в 56 км к северо-западу от пос. Уренгой.

Уренгойское месторождение входит в состав Уренгойского нефтегазоносного района Надым-Пурской нефтегазоносной области (НГО). Характерная особенность этой области - развитие мощного (до 2000 м) мелового (неоком-сеноманского) ком- плекса, который заключен между двумя регионально выдержанными глинистыми толщами. Основные залежи газа, приуроченные к сеноманским отложениям, залегают непосредственно под региональной покрышкой верхнемеловых (туронских) и палеогеновых отложений. Газоконденсатные залежи присутствуют также в ачимовской толще и отложениях юрского комплекса $[1,3]$.

Территория севера Западной Сибири в период от валанжина до сеномана испытывала преимущественно континентальный режим осадконакопления, тогда существовали благоприятные условия для захоронения растительных остатков - исходного материала для массы угольного 
вещества, содержащегося в породах комплекса. В указанный период отмечались отдельные эпохи максимального угленакопления (баррем-апт-сеноман), которые привели к концентрированным формам скопления в виде пластов угля. Число угольных пластов 10-30, а их суммарная толщина - десятки метров $[4,6]$. Наличие повышенных концентраций угольного вещества (как в рассеянной, так и в концентрированной форме) явилось важнейшим генетическим признаком, по которому континентальная толща покурской серии апт-сеноманского возраста отнесена к типичной угленосной формации.

Степень катагенеза углей по отражательной способности витринита $\mathrm{R}^{\mathrm{A}}(\%)$ различных горизонтов неоком- сеноманского комплекса колеблется от 5,5 до 7,5, что соответствует стадиям преобразования углей от бурой до длиннопламенной (табл. 1). Можно выделить два фазово-генетических типа газоконденсатных скоплений. «Первичные» (без нефтяных оторочек) характеризуются низким содержанием конденсата, находятся ниже главной зоны нефтеобразования (ГЗН), образуются непосредственно из органического вещества в зоне наиболее «жесткого» катагенетического преобразования пород. «Вторичные» приурочены к газонефтяным системам, отличаются высоким содержанием конденсата, расположены выше ГЗН и формируются при растворении легких фракций нефтей в сжатых газах.

Таблица 1. Приниипиальная схема сопоставления шкал катагенеза и углефикации ОВ и вертикальной зональности нафтидогенеза (по Н.Б. Вассоевичу, 1990) [10]

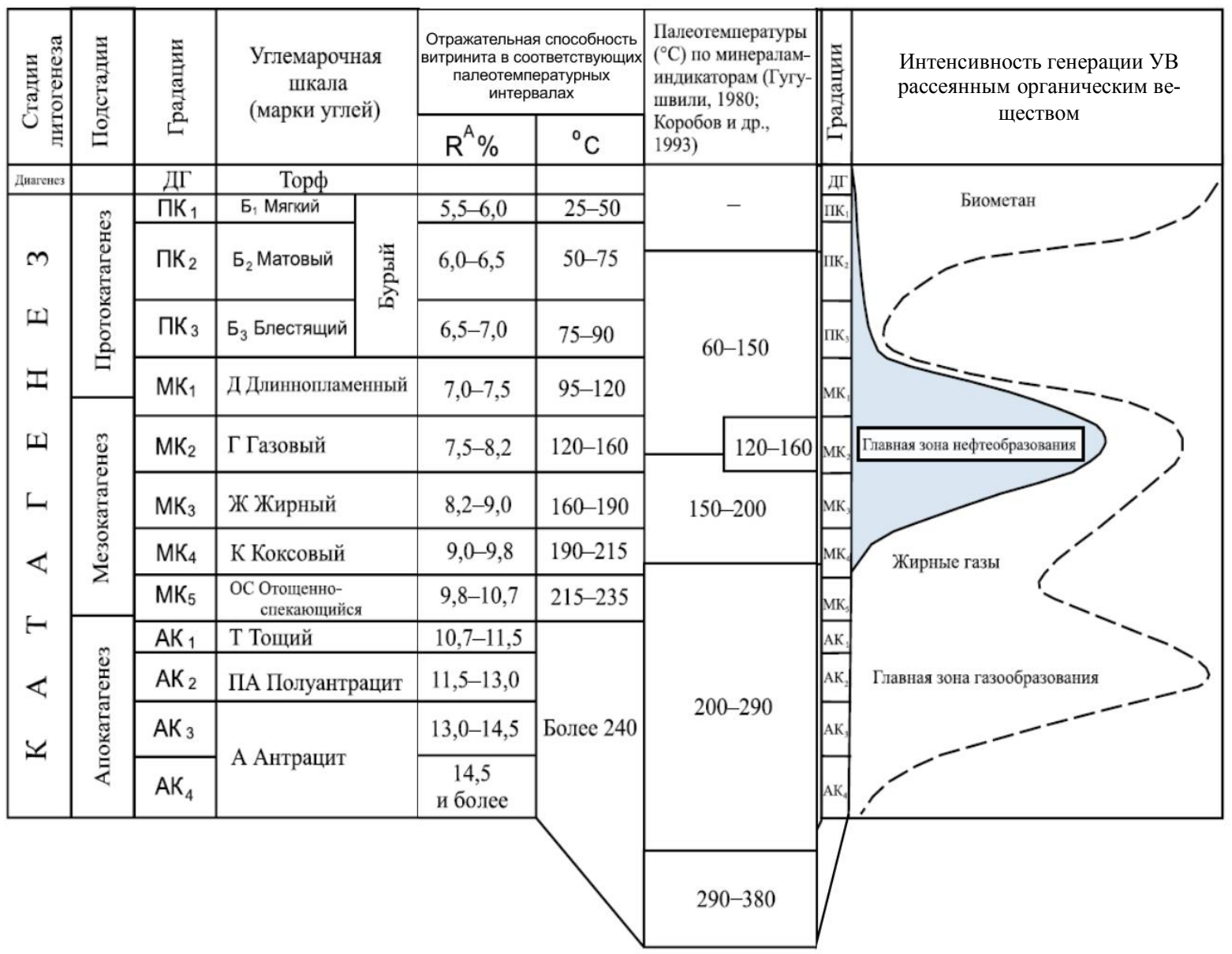

Основные характеристики залежей приведены в табл. 2. Содержание УВ увели- чивается с глубиной. Для нижней части мелового комплекса (неоком) характерны 
газоконденсатные залежи с нефтяными оторочками и наибольший предположительный выход УВ, которые образовались из сапропелевого типа УВ.

Углеводородные газы образуются в процессе изменения органического вещества (OB) от буроугольной до антрацитовой стадии [2-5]. Поэтому и газоконденсатные системы, тесно связанные с газовыми, могут быть встречены в широком диапазоне глубин. Это позволяет полагать, что «первичные» газоконденсатные системы на севере Западной Сибири могут быть встречены в широком стратиграфическом диапазоне от сеномана до юры.
Суммарное содержание угольного вещества в толще мелового комплекса оценивается в $15,5 \cdot 10^{12}$ т, из которых $6,9 \cdot 10^{12}$ т в отложениях покурской серии (апт - альб сеноман) имеют буроугольную стадию катагенеза и $8,6 \cdot 10^{12}$ т в отложениях готерив-баррема - начальную длиннопламенную стадию. Угольное вещество на буроугольной стадии катагенеза генерирует гомологи метана. В больших концентрациях они отмечены на длиннопламенной, газовой и жирной стадиях катагенеза. Кроме гомологов метана из угольного вещества образуются жидкие углеводороды (УB) $[3,7,8,9]$.

Таблица 2. Характеристика газоконденсатных залежей

\begin{tabular}{|c|c|c|c|c|c|}
\hline \multirow{2}{*}{$\begin{array}{c}\text { Зоны } \\
\text { нефтегазообразования }\end{array}$} & \multirow{2}{*}{ Тип керогена } & \multirow{2}{*}{ 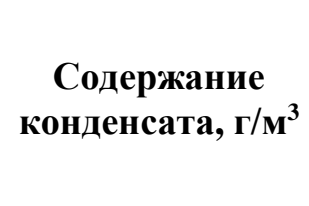 } & \multicolumn{3}{|c|}{$\begin{array}{l}\text { Предположительный вы- } \\
\text { ход углеводородов }\left(10^{12} \text { т) }\right.\end{array}$} \\
\hline & & & Метан & Битумы & Итого \\
\hline Сеноман & Сапропелевый & $0,03-3$ & 0,097 & 0,307 & 0,404 \\
\hline Апт & Гумусовый & $0,65-80$ & 0,230 & 0,049 & 0,279 \\
\hline \multirow{2}{*}{ Неоком } & Гумусовый & \multirow{2}{*}{$100-350$} & 0,273 & 0,063 & 0,336 \\
\hline & Сапропелевый & & 0,385 & 1,406 & 1,791 \\
\hline Ачимовский & Гумусовый & до 680 & & & \\
\hline Юрский & $\begin{array}{l}\text { Сапропелево- } \\
\text { гумусовый }\end{array}$ & до 800 & & & \\
\hline
\end{tabular}

Коэффициент аккумуляции для газа в месторождениях Западной Сибири составляет 0,15 , что свидетельствует о высоком газовом потенциале, играющем определяющую роль при формировании газоконденсатных залежей [6]. Следовательно, «первичные» конденсаты (не связанные с нефтью) могли образоваться в отложениях мелового комплекса на стадиях мезокатагенеза (МК1 - МК3) из ОВ гумусового типа.
Таким образом, в северных районах Западной Сибири, на Уренгойском месторождении в частности, в верхней части мелового комплекса развиты «первичные» нафтеновые газоконденсаты, образовавшиеся на буроугольной стадии катагенеза OB гумусового типа и связанные с крупной зоной газонакопления, приуроченной к области развития угленосной формации. Выделяемая «переходная» зона преимущественного развития газоконденсатнонефтяных залежей характеризуется зако- 
номерным соотношением нефтяных и газоконденсатных залежей. Рассмотренная вертикальная и региональная зональность распределения фазового состояния УВ позволяет прогнозировать фазовое состояние, количественную и качественную характеристики скоплений УВ в юрском нефтегазоносном комплексе на севере Западной Сибири.

В юрских отложениях следует ожидать развитие газоконденсатных залежей преимущественно метанового состава с высоким содержанием конденсата, о чем свидетельствует наблюдаемая тенденция увеличения концентрации конденсата до $600 г / \mathrm{m}^{3}$ на глубине 5000 м на Уренгойском месторождении.

\section{Библиографический список}

1. Гончаров И. В., Обласов Н.В., Самойленко B.B. и др. Нефтематеринские породы и нефти восточной части Западной Сибири // Нефтяное хозяйство. 2010. № 8. С. 24-28.

2. Гончаров И. В., Самойленко В.В., Обласов $H . B$. и др. Катагенез органического вещества пород баженовской свиты юговостока Западной Сибири (Томская область) // Там же. 2013. № 10. С. 32-37

3. Конторович А.Э., Нестеров И.И., Салманов Ф.К. и др. Геология нефти и газа Западной Сибири. М.: Недра, 1975. 679 с.
4. Коробов А.Д., Коробова Л.А., Ахлестина $E . \Phi$. Минералогические и палеогеотермические критерии нефтегазоносности рифтогенных осадочных бассейнов // Известия Саратовского университета. Новая серия. Сер. Науки о Земле. 2009. Т. 9, вып. 2. C. 28-35.

5. Литвин В. В., Михайлова С. В., Захарова O. A. u $\partial p$. Перспективы нефтеносности ачимовских отложений в центральной части Ноябрьского региона Западной Сибири // Нефтяное хозяйство. 2013. № 12. С. 1719.

6. Немченко Н.Н., Ровенская А.С. Углистое вещество как возможный источник газа при формировании газовых месторождений севера Тюменской области // Геология и разведка газовых и газоконденсатных месторождений. 1968. № 1. С. 51-60.

7. Немченко Н.Н. Раздельный прогноз углеводородных систем Западной Сибири: автореф. дис. ... д-ра геол.-мин. наук. М., $1991.28 \mathrm{c}$.

8. Скоробогатов В.А., Строганов Л.В., Kопеeв В.Д. Геологическое строение и газонефтеносность Ямала. М.: Недра, 2003. 352 с.

9. Шустер В. Л., Пунанова С. А. Вероятностная оценка перспектив нефтегазоносности доюрского комплекса Западной Сибири с помощью геолого-математической программы «Выбор» // Нефтяное хозяйство. 2014. № 1. C. 16-19

10.ROGTEC [Электронный источник]. URL: http://www.rogtecmagazine.com/

\section{Origin of Natural Gas of the Giant Urengoy Deposit}

A.V. Plyusnin, O.E. Kochneva

Perm State National Research University, 614990, Perm, Bukirev St., 15

E-mail: geolog0112@mail.ru

This article presents the discussion on the geological structure and origin of the large Cretaceous Neocomian-Cenomanian Complex, which is characteristic for Urengoy deposit of Nadym-Pur Oil and Gas Province. In period from the Valanginian to Cenomanian, this territory experienced predominantly continental depositional regime, provided the favorable conditions for accumulation of large amount of plant remnants, which were a raw material for the coal strata of the complex. The presence of high concentration of organic substance was the most important genetic characteristics of Aptian-Cenomanian continental strata that constitute a typical coal-bearing formation. The analysis of obtained information allowed to predict the phase state of hydrocarbon accumulation at the area.

Key words: Western Siberia, Nadym-Pur oil and gas province, Urengoy field, Cenomanian, gas, condensate, catagenesis. 


\section{References}

1. Goncharov I. V., Oblasov N.V., Samoylenko V.V. et al., 2010. Neftematerinskiye porody i nefti vostochnoy chasti Zapadnoy Sibiri [Petroleum source rocks and the eastern part of Western Siberia]. Neftyanoye khozyaystvo, 8:24-28.

2. Goncharov I. V., Samoylenko V.V., Oblasov $N . V$. i dr. Katagenez organicheskogo veshchestva porod bazhenovskoy svity yugovostoka Zapadnoy Sibiri (Tomskaya oblast) [Catagenesis organic matter of the Bazhenov Formation rocks of southeastern West Siberia (Tomsk region)]. Neftyanoye khozyaystvo, № 10, 2013, pp 32-37.

3. Kontorovich A.E., Nesterov I.I., Salmanov F.K. i dr. Geologiya nefti i gaza Zapadnoy Sibiri [Oil and gas geology of Western Siberia]. Nedra, Moscow, 1975, 679 p.

4. Korobov A.D., Korobova L.A., Akhlestina $Y e . F$. Mineralogicheskiye i paleogeotermicheskiye kriterii neftegazonosnosti riftogennykh osadochnykh basseynov [Mineralogical and paleogeotermicheskie criteria petrogas rifting sedimentary basins]. Izvestiya Saratovskogo universiteta, V. 9, 2009, pp 28-35

5. Litvin V. V., Mikhaylova S. V., Zakharova $O$. $A$. Perspektivy neftenosnosti achimovskikh otlozheniy v tsentralnoy chasti Noyabrskogo regiona Zapadnoy Sibiri [Prospects of oilbearing deposits Achim in the central part of the November region of Western Siberia].
Neftyanoye khozyaystvo, № 12, 2013, pp 1719.

6. Nemchenko N.N., Rovenskaya A.S. Uglistoye veshchestvo kak vozmozhnyy istochnik gaza pri formirovanii gazovykh mestorozhdeniy severa Tyumenskoy oblasti [Carbonaceous matter as a possible source of gas in the formation of gas fields north of the Tyumen region]. Geologiya i razvedka gazovykh i gazokondensatnykh mestorozhdeniy, № 1, 1968, pp 51-60.

7. Nemchenko N.N. Razdelnyy prognoz uglevodorodnykh sistem Zapadnoy Sibiri. [Separate prediction of hydrocarbon systems in Western Siberia]. Avtoref. dis. d-ra geol.-miner. Nauk, Moscow, 1991, $28 \mathrm{p}$.

8. Skorobogatov V.A., Stroganov L.V., Kopeyev V.D. Geologicheskoye stroyeniye i gazoneftenosnost Yamala [Geological structure and Yamal gas and oil presence]. Nedra, Moscow, 2003, 352 p.

9. Shuster V. L., Punanova S. A. Veroyatnostnaya otsenka perspektiv neftegazonosnosti doyurskogo kompleksa Zapadnoy Sibiri s pomoshchyu geologo-matematicheskoy programmy «Vybor» [Probabilistic assessment of the petroleum potential of the pre-Jurassic complex of Western Siberia using geological and mathematical program "Choice"]. Neftyanoye khozyaystvo, № 1, 2014, pp 16-19

10.ROGTEC - Elektron. dan. - Rezhim dostupa: http://www.rogtecmagazine.com/ 